\title{
THE NEW UTRICULARIA SPECIES DESCRIBED SINCE PETER TAYLOR'S MONOGRAPH
}

Andreas Fleischmann - University of Munich, LMU - Department of Systematic Botany and Mycology•Menzinger Strasse 67 • 80638 Munich•Germany•fleischmann@1rz.uni-muenchen.de

In his elaborate monograph of the genus Utricularia (Lentibulariaceae), Peter Taylor recognized 214 species of bladderworts. For this comprehensive revision of that large genus, which took him 41 years of passionate work, he studied the plants in their natural habitats and such cultivated in the greenhouses of Kew Gardens, but mainly his work is based on the thousands of herbarium specimens from all over the world that he thoroughly examined. As the bladderworts are a large and species-rich genus, and many species are often difficult to distinguish (several only with the aid of a magnifying glass by minute seed and trap details), a lot of different species and names have been published for over 200 years since Linnaeus put up the genus in 1753. Peter Taylor took the Sisyphean task to work through the more than 900 names for taxa of Utricularia that had been published. He studied and compared type specimens and descriptions, and finally was able to recognize that more than $3 / 4$ of the names were actually representing synonyms of already described taxa, or invalid names. His all-encompassing monograph left nothing more to add!

In the 22 years that have passed since, about two dozen new species of Utricularia have been discovered and described. The ones which are considered to represent taxonomic novelties (in the personal opinion of this author) are discussed in more detail below. This brings the total number of accepted species in the genus Utricularia to at least 228 today. For synonymy and further names published since 1989 see the checklist at the end of this article.

\section{Subgenus Polypompholyx ${ }^{l}$}

From Western-Australia, two additional species have since been described from $U$. section Pleiochasia (i.e. from the affinity of $U$. dichotoma). The annual Utricularia petertaylorii and the perennial U. paulineae (Lowrie 1998, 2002), both with rather large, showy flowers (see Figs. 1 and 2). The later species is named after Allen Lowrie's wife Pauline, who initially discovered the plant. The former honours Utricularia specialist Peter Taylor - who, by the way, was already aware of a population of this beautiful plant, however considered it to represent a possible hybrid swarm between U. violacea and U. inaequalis (Lowrie 1998).

From southeast Australia, a further species has been added to $U$. section Pleiochasia: the rarely found, annual U. beaugleholei (Gassin 1993). This species is closely related to the perennial $U$. dichotoma, however differs in its narrowly lanceolate acute leaves, different traps, and a different flower-shape (see Fig. 3).

\section{Subgenus Bivalvaria}

The stunningly deep blue-flowered $U$. babui was originally described from the Western Ghats of western India (Yadav et al. 2005), however has since been found in northern Thailand as well

\footnotetext{
${ }^{1}$ The infrageneric classification used here for the genus Utricularia is following Müller \& Borsch (2005)
} 

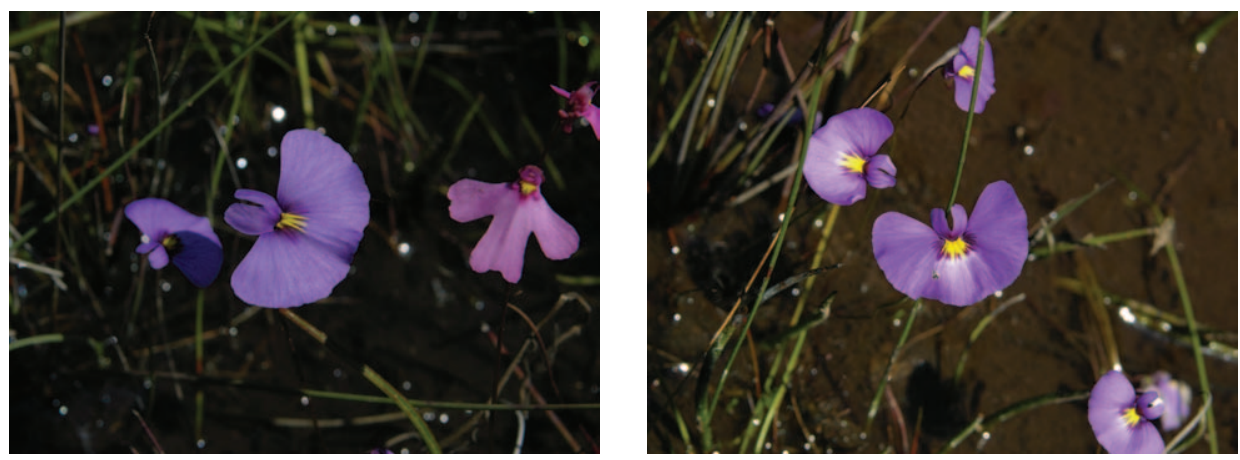

Figure 1: Utricularia petertaylorii, an annual bladderwort species from Western Australia that was named in honour of Peter Taylor. The plants on the left are growing together with U. multifida.
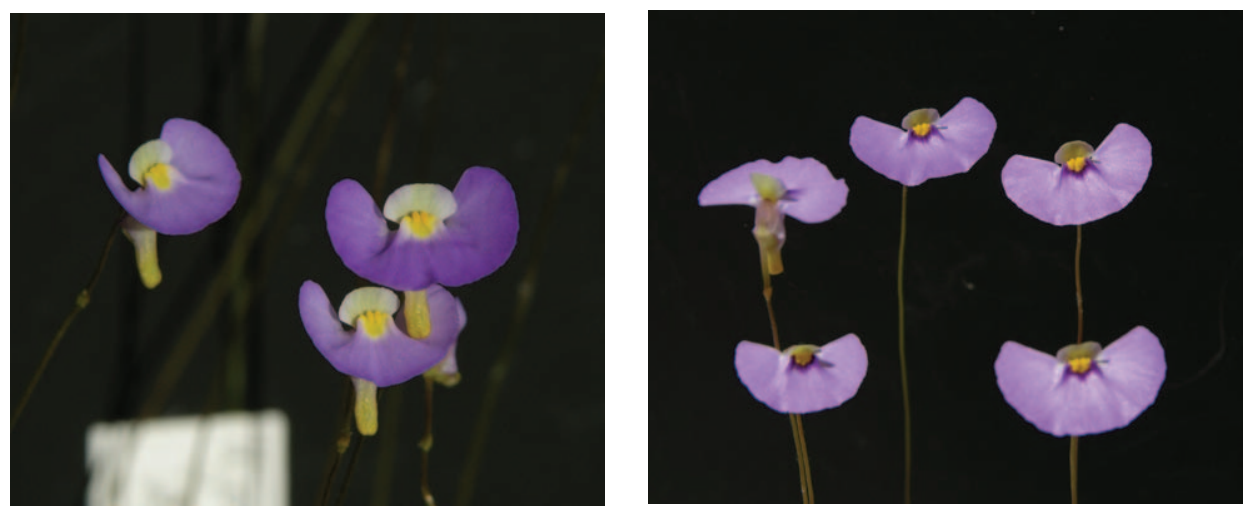

Figure 2: The showy flowers of Utricularia paulineae, plants cultivated by the author. On the left plants from the type location near Walepole, on the right plants with slightly distinct corolla shape and coloration from a different location in south-west Western Australia.

(see Fig. 4; A. Fleischmann, pers. obs. 2005; Suksathan \& Parnell 2010). It obviously is closely related to $U$. graminifolia, from which it differs mainly in having narrower leaves which are vascularised by only a single vein (three nerves in the leaves of U. graminifolia).

Utricularia subramanyamii from southern India (Janarthanam \& Henry 1990) was described to be unique among Indian Utricularia mainly because of a "diagnostic ligule" (Janarthanam \& Henry 1990, 1992) on the palate of the lower lip, however a quite similar projection is also found regularly on the gibbous palate of $U$. capillacea - formerly U. scandens - a variable species widespread in the Old World tropics (see Fig. 5). However U. subramanyamii further differs from that species by its very short pedicels and different seed shape, and thus is considered a distinctive species here.

All other species that have been described from the large and taxonomically difficult $U$. section Oligocista since Taylor's treatment in 1989 are considered of doubtful taxonomic value, and are included in the synonym list at the end of this article. E.g. U. malabarica is perfectly matching Taylor's U. praeterita in all morphological characters (including fruiting pedicel pattern and seed shape). Utricularia jackii (Parnell 2005) is based on a mixed collection of $U$. 

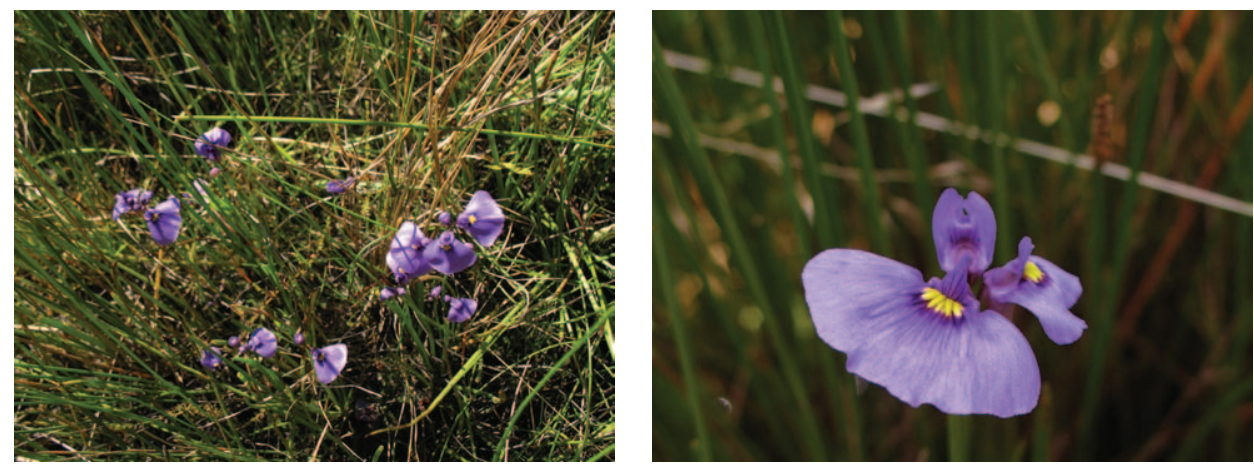

Figure 3: Utricularia beaugleholei in habitat in southern Australia and close-up of a flower. The flowers resemble those of the related $U$. dichotoma, however the latter has fewer yellow rims on the palate. Photos by Steve Fretwell.
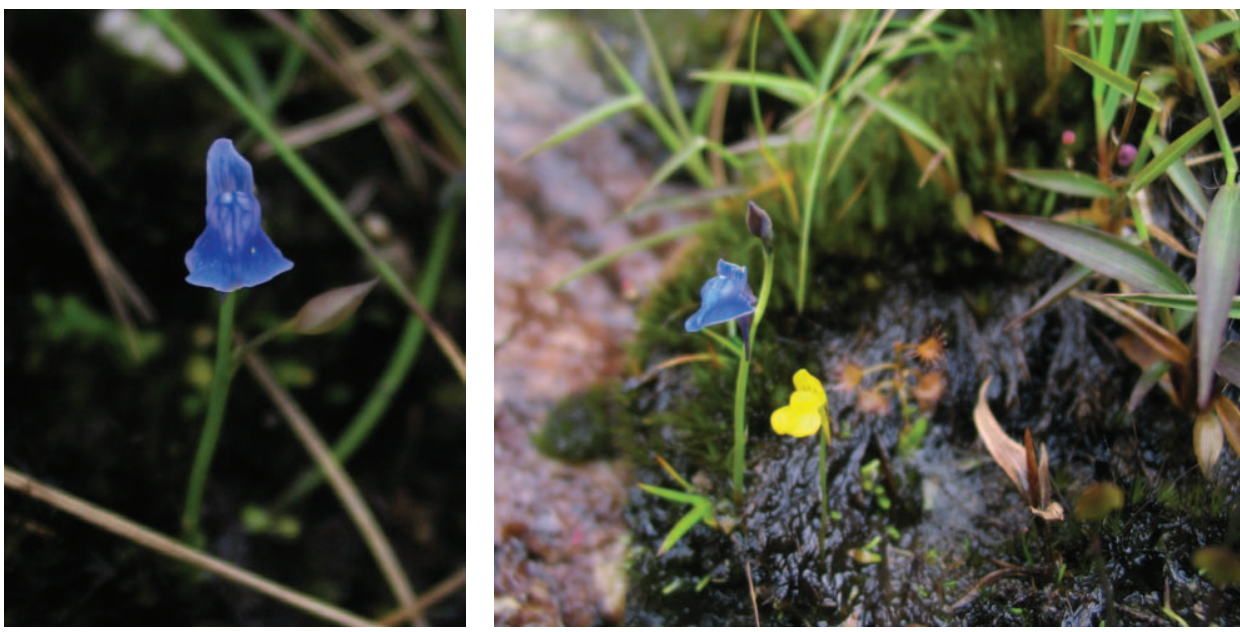

Figure 4: The bright ink-blue flowers of Utricularia babui plants, growing on Doi Inthanon of northern Thailand. At this location, the plants were growing sympatrically with a stunted form of $U$. recta (yellow flower on the right photo), which has been described as $U$. jackii (Parnell 2005).

babui (a single specimen on the holotype sheet) and stunted specimens of the yellow flowered $U$. recta ${ }^{2}$, which both grow sympatrically on Doi Inthanon of northern Thailand (see Fig. 4). Utricularia janarthanamii from the Western Ghats of India (Yadav et al. 2000) is perfectly matching the Philippine endemic U. heterosepala in all of its remarkable morphological characters - the absence of bracteoles (due to fusion with the bracts), a rather unusual feature in this group of bladderworts, as well as the unique and distinctive seeds with finely sinuate testa ornamentation. Therefore it is regarded as conspecific with $U$. heterosepala here, and extends the range of that species to western India. Like a few other species of Utricularia, U. janarthanamii is reported to exhibit both chasmogamous flowers with well-developed corollae, as well as much smaller cleistogamous flowers, the latter even developing underground (Yadav et al. 2000; Sardesai \&

\footnotetext{
${ }^{2}$ or likewise robust specimens of U. capillacea (formerly known as U. scandens)
} 

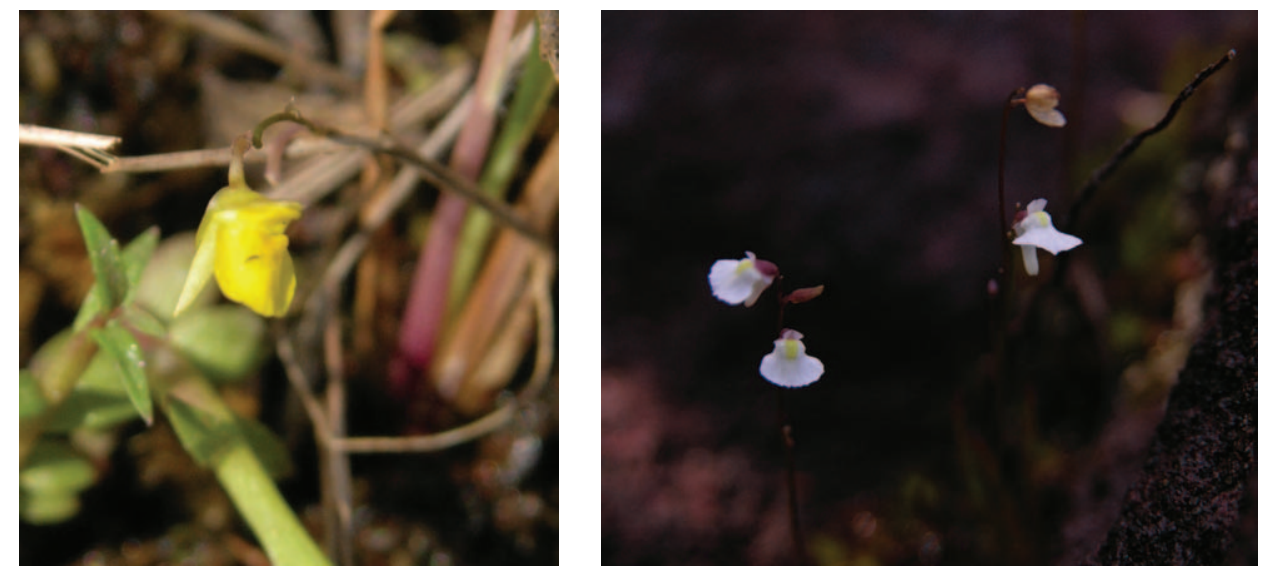

Figure 5 (left): Utricularia capillacea, an old species with a "new" name. This species was called U. scandens in Taylor's monograph, however it recently became evident that this name actually represents a younger synonym of $U$. capillacea. This photo shows a plant growing in Zambia.

Figure 6 (right): The delicate Utricularia rostrata growing in cracks of wet rock at the Chapada Diamantina, Brazil. Note the capsule, with a spreading lower calyx lobe which acts for seed dispersal.

Yadav 2008). This feature is not known from the Philippine plants, however might represent an adaptation to the ephemeral habitats of the Indian populations. Utricularia naikii agrees with cleistogamous specimens of $U$. praeterita, a species with which it is reported to occur sympatrically (Yadav et al. 2000). The Brazilian U. densiflora (Souza \& Bove 2011) seems to represent a stunted specimen of the sympatrically occurring $U$. erectiflora, with a strongly congested raceme (these compact specimens frequently occur among normal sized plants, and already had been described as U. micrantha Benj. and U. cearana Steyerm. respectively (Taylor 1989)). The papillose subterranean parts of $U$. erectiflora have also been described and depicted by Taylor (1989) already, and apparently these glands are also found up to the base of the scape of some specimens.

A single species was added to $U$. section Aranella in 2009, namely $U$. rostrata, a widespread and rather common species from the mountains of the Chapada Diamantina range of Bahia state, Brazil (Fleischmann \& Rivadavia 2009). It has small whitish or violet flowers (see Fig. 6), and differs from all members of the same affinity by flower and calyx characters. This species already has entered several carnivorous plant collections under the informal name " $U$. sp. Chapada Diamantina", and it proved to be a weedy grower easily spreading from seed, like U. subulata.

From the poorly-studied section Phyllaria (the Asian lithophytic or epiphytic, moss-dwelling species related to U. striatula), three new species have been described from northern Thailand recently, all from high mountain summits (see Fig. 7; Suksathan \& Parnell 2010). Two of them have been named after their type location: $U$. inthanonensis is endemic to Doi Inthanon (the highest peak of Chiang Mai province), U. phusoidaoensis to Phu Soi Dao of Phitsanulok province. The third one, U. spinomarginata, has seeds with a spiny testa surface (like many members of this group of bladderworts, most likely in adaptation to their moss-growing or lithophytic habit), and the specific epithet is referring to that character. 

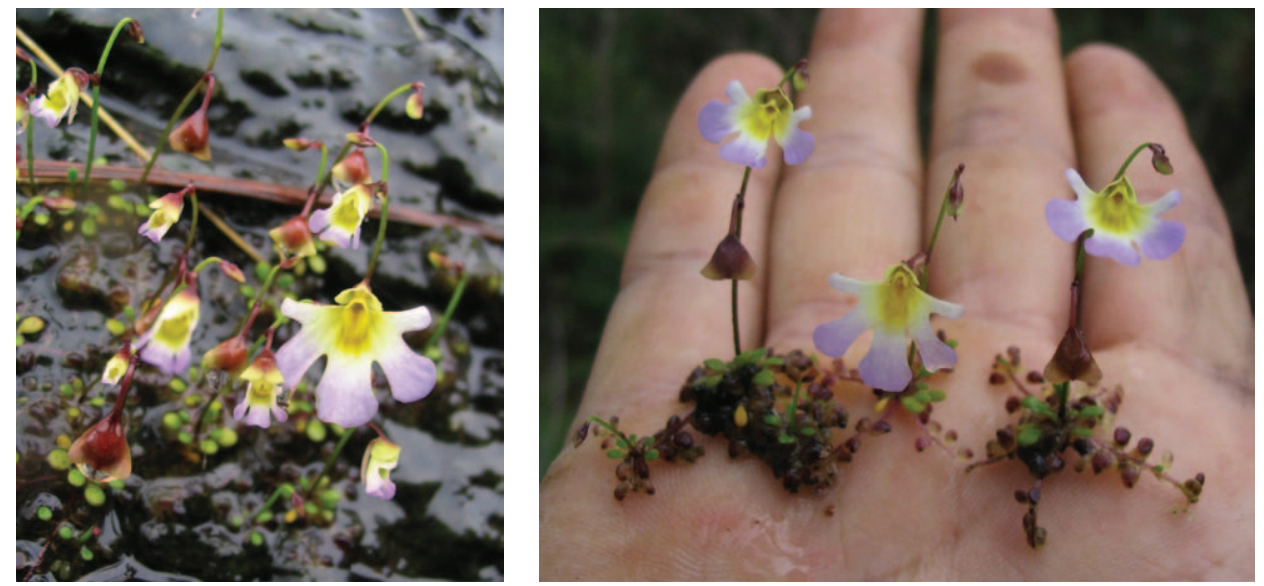

Figure 7: The impressive flowers of Utricularia inthanonensis, growing on wet vertical rocks on Doi Inthanon, northern Thailand.

The Asian highland rainforest species of Utricularia section Phyllaria are indeed highly overlooked (and underestimated), both in regards of diversity, as well as the distribution of certain species: Utricularia furcellata, hitherto regarded as an endemic of Himalayan India (Taylor 1989), has recently been found at several sites in northern Thailand (A. Fleischmann pers. obs. 2005; Suksathan \& Parnell 2010). Another species of the same group, U. moniliformis, which was thus far thought to be endemic to mountains of central Sri Lanka (Taylor 1989) has recently been found in Borneo, Sumatra and the Philippines (Palawan) on various occasions by several carnivorous plant enthusiasts (Ch. Klein, pers. com., K. Pasek, pers. com., S. McPherson, pers. com.). This perennial species, which forms little tubers, has shown to be the most easy to grow in long-term cultivation,
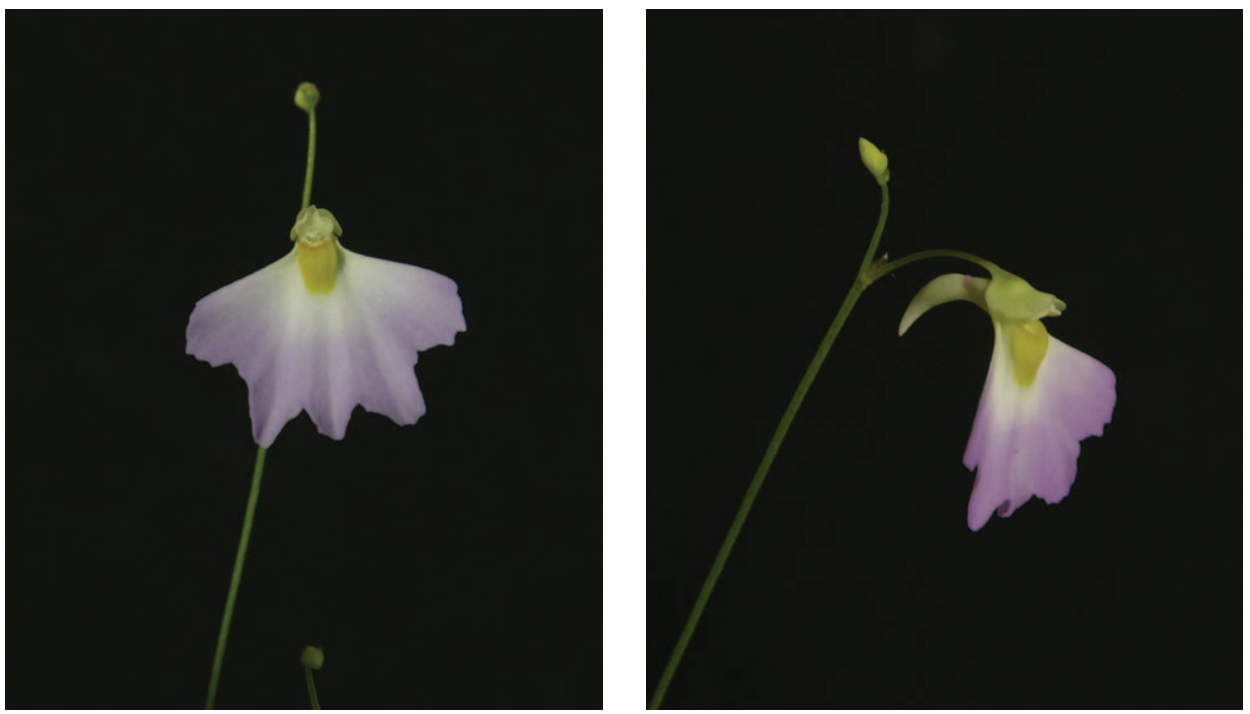

Figure 8: Utricularia moniliformis of Utricularia section Phyllaria, cultivated by the author. Not new to science, but much more widespread than Taylor (1989) assumed at the time, and one of the very few species of that intriguing group which seem to last in cultivation. 

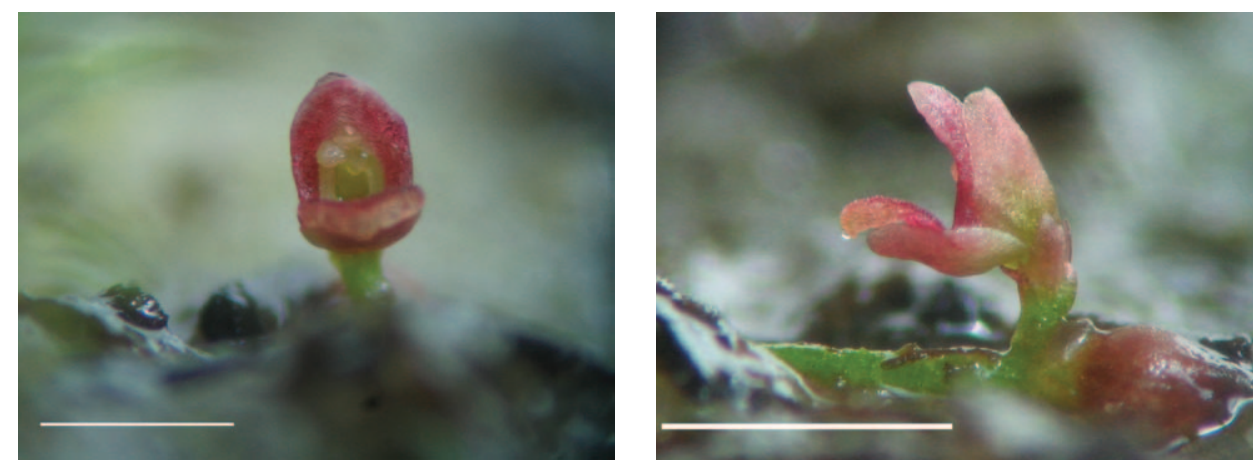

Figure 9: The microscopic flower of Utricularia simmonsii, from a plant cultivated by the author. The scale bar is $1 \mathrm{~mm}$.

out of these really picky lithophytes, and actually the majority of plants currently grown as " $U$. striatula" in carnivorous plant collections in fact represent U. moniliformis (see Fig 8).

To the small $U$. section Kamienskia of southeastern China, which thus far only comprised a single, enigmatic and locally endemic species - U. peranomala - a second curious, narrowly endemic and even more poorly-known species has been added recently: $U$. mangshanensis from the Mangsha Mountains of Hunan Province, China (Hu et al. 2007). Like its closely related sister, it grows as a lithophyte on moss-covered wet rocks, and differs from that species by having whitish flowers and distinctive irregularly lobed leaves.

The smallest bladderwort species known today (and probably also the angiosperm with the smallest fully-developed corolla) was rather fortuitously discovered in tropical northern Australia by Allen Lowrie and co-workers, and named in 2008 as U. simmonsii - after the original discoverer of this lucky dip (Lowrie et al. 2008). The tiny corolla of this new species is just about one millimetre long, but bright purple-red, with widely open throat, lacking both a palate and spur (see Fig. 9). This plant apparently has been overlooked before due to its diminutive size, but it seems to be rather widespread in the Northern Territory and in northern Queensland. The authors proposed a separate section for this curious new species, $U$. section Minutae, however recent molecular phylogenetic reconstructions (Reut \& Jobson 2010) revealed that $U$. simmonsii is closely allied with $U$. section Enskide (thus far only comprising two tropical Australian species, namely U. fulva and the polymorphic $U$. chrysantha), a position which is also supported by morphological characters like common trap design and a similar seed structure.

\section{Subgenus Utricularia}

A newly described species from the remote Sierra Madre del Sur, Guerrero, Mexico, which has flowers that are remarkable both in coloration and shape, is the annual U. regia (see Fig. 10; Zamudio \& Olvera 2009). This species belongs to U. section Foliosa (formerly Taylor's section Psyllosperma, which got included in section Foliosa based on molecular evidence, see Müller \& Borsch 2005), and is closely related to two other Mexican endemic species from that group (U. hintonii and $U$. petersoniae). From all known Utricularia species, it can be distinguished by its deeply bilobate upper lip with bifid lobes, and a marking on the lower lip which resembles an inverted crown (hence the species' name).

One additional aquatic species of $U$. section Utricularia from the northern hemisphere that 

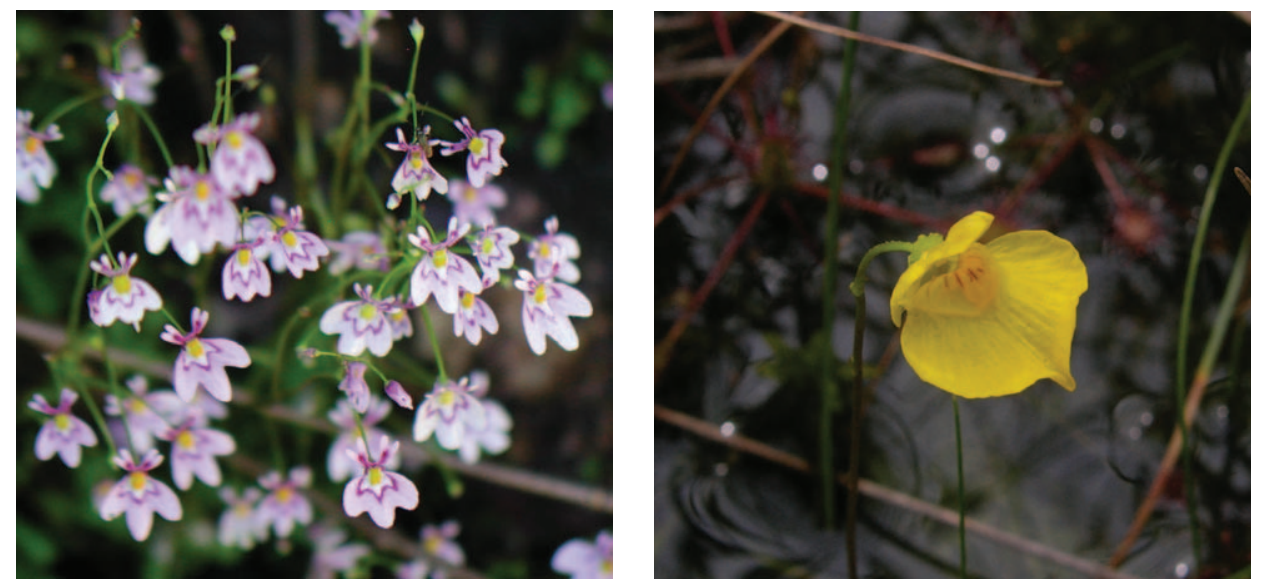

Figure 10 (left): Utricularia regia from the type location in Mexico. Note the deeply bifid, spreading upper corolla lobes, and the characteristic mark on the lower lip, resembling an inverted, 3-pronged crown. Photo by Ricardo de Santiago.

Figure 11 (right): Utricularia stygia, growing in a bog in southern Germany, accompanied by Drosera intermedia. This temperate bladderwort species was formally described at the time Taylor's monograph had already been completed, and thus is not separately included in that work.

has been formally described in 1988, shortly before Taylor's monograph was printed, was already mentioned in that work, however without being included as a distinct species: U. stygia (see Fig. 11; Thor 1988). It was tentatively treated under U. ochroleuca in Taylor's monograph, in order to get his four decades work to a final end (" [...] I am unable to assess its status without further delaying the publication of this present work." Taylor 1989). This hitherto neglected species probably is the most common Utricularia species of temperate hill moors and Sphagnum peat bogs (together with the often sympatric occurring $U$. minor), where it usually grows in small acidic pools and mud bottoms. However it has often been mistaken for the superficially similar $U$. intermedia in the past, or been lumped with the even more reminiscent $U$. ochroleuca. Several recent publications are dealing with the distribution, ecology, morphology, and taxonomy of $U$. stygia (for a detailed treatment, see e.g. Schlosser 2003).

The free-floating aquatic Utricularia tenuicaulis from Japan, which has been considered to be conspecific with $U$. australis by most authors (including Taylor 1989), has recently been found to actually represent one of the parent species of the diploid sterile hybrid $U$. australis (which originated from natural asymmetric hybridization between U. tenuicaulis (female) and U. macrorhiza (male); Kameyama et al. 2005). It therefore is considered as a species distinct from the widespread, sterile $U$. australis here (although not so much morphologically distinct, but reproductively separated, see Kameyama \& Ohara 2006). Whether U. australis is indeed a diploid hybrid throughout its range (and should thus be best classified as $U$. $\times$ australis), or also contains amphiploid populations remains unclear yet.

\section{Checklist of the Utricularia species to add to Taylor's monograph from 1989}

Accepted taxa in bold, synonyms in regular font. The source publication is given abbreviated, the year of publication in parenthesis. The distribution for accepted taxa is given with country and lower geographical unit (states or provinces) where these species occur. 


\section{Taxa described since Taylor's monograph from 1989}

Utricularia aurea Lour. var. gracilis (Oliv.) Phuong - Danh luc cac loai thuc vat viet nam 3: 248 (2005). nom. inval. = aurea Lour.

Utricularia australis R.Br. var. tenuicaulis (Miki) Hatus. - Fl. Ryukyus, ed. 2: 204, without basionym reference (1994). = tenuicaulis Miki

Utricularia babui S.R.Yadav, Sardesai \& S.P.Gaikwad - Rheedea 15: 71 (2005). India (Maharashtra), Thailand (Chiang Mai).

Utricularia beaugleholei Gassin - Muelleria 8: 37 (1993). Australia (Victoria, New South Wales, South Australia).

Utricularia bentensis Komiya - Bull. Nippon Dent.Univ.Gen.Educ.26:184 (1997) = bremii Heer.

Utricularia catolesensis G.L.Campos, Cheek \& Giul. - Sitientibus Sér. Ci. Biol. 10: 233 (2010)= rostrata A.Fleischm. \& Rivadavia

Utricularia chiakiana Komiya \& C.Shibata - Bull. Nippon Dental Univ. Gen. Educ. 26: 209 (1997) = gibba L.

Utricularia cochleata C.P.Bove - Revista Brasil. Bot. 31: 555 (2008) = ? subulata L. (mixed with fern leaves?)

Utricularia cornigera Studnička - Thaiszia 19: 135 (2009) = reniformis A.St.-Hil. / ? reniformis A.St.-Hil. x nelubmifolia Gardn.

Utricularia densiflora P.C. Baleeiro Souza \& C.P. Bove - Systematic Botany 36: 465 (2011). = erectiflora A.St.-Hil. \& Girard

Utricularia humboldtii R.H.Schomb. f. albiflora Komiya \& C.Shibata - Bull. Nippon Dental Univ. Gen. Educ. 26: 210 (1997) = humboldtii R.H.Schomb.

Utricularia inthanonensis Suksathan \& J.Parn. - Thai Forest Bulletin, Botany 38: 25 (2010). Thailand (Chiang Mai).

Utricularia jackii J.Parn. - Thai Forest Bulletin, Botany 33: 128 (2005). = recta P.Taylor (based on a mixed collection with $U$. babui)

Utricularia janarthanamii S.R.Yadav, Sardesai \& S.P.Gaikwad - Rheedea 10: 107 (2000). = heterosepala Benj.

Utricularia linearis Wakabayashi - J. Insectiv. P1. Soc. 61: 90 (2010) = fistulosa P.Taylor

Utricularia malabarica Janarth. \& A.N.Henry - J. Bombay Nat. Hist. Soc. 86 : 84 (1989). = praeterita P.Taylor

Utricularia mangshanensis G.W.Hu - Ann. Bot. Fenn. 44: 389 (2007). China (Hunan).

Utricularia naikii S.R.Yadav, Sardesai \& S.P.Gaikwad - Rheedea 10: 110 (2000). = praeterita P.Taylor (cleistogamous plants of that species).

Utricularia paulineae Lowrie - Nuytsia 12: 38 (1998). Australia (Western Australia).

Utricularia petertaylorii Lowrie - Nuytsia 14: 406 (2002). Australia (Western Australia).

Utricularia phusoidaoensis Suksathan \& J.Parn. - Thai Forest Bulletin, Botany 38: 27 (2010). Thailand (Phitsanulok).

Utricularia regia Zamudio \& Olvera - Brittonia 61: 119 (2009). Mexico (Guerrero).

Utricularia ramosissima Wakabayashi - J. Insectiv. P1. Soc. 61: 35 (2010)= geoffrayi Pellegr. (the spur length in this species seems to be more variable, and aged scapes of both $U$. geoffrayi and U. minutissima frequently branch in cultivation).

Utricularia rostrata A.Fleischm. \& Rivadavia - Kew Bulletin 64: 155 (2009). Brazil (Bahia).

Utricularia simmonsii Lowrie, Cowie \& Conran - Telopea 12: 32 (2008). Australia (Northern Territory, Queensland).

Utricularia spinomarginata Suksathan \& J.Parn. - Thai Forest Bulletin, Botany 38: 27 (2010). Thailand (Phitsanulok). 
Utricularia subramanyamii Janarth. \& A.N.Henry - J. Bombay Nat. Hist. Soc. 87: 441 (1991), as 'subramanii'. India (Kerala). (=? capillacea Willd.)

Utricularia uxoris Gómez-Laur. - Lankesteriana 5: 137 (2005) = jamesoniana Oliv. (specimen with atypical unripe or malformed corolla)

\section{Names rejected by Taylor, but accepted by the author of this article}

Utricularia stygia Thor - Nordic J. Bot. 8: 219 (1988). Circumboreal (widespread in temperate Europe, Asia and North America).

Utricularia tenuicaulis Miki - Bot. Mag. Tokyo 49: 847 (1935). Japan (exact range unknown).

\section{Species treated under a different name by Taylor 1989}

Utricularia capillacea Willd. - Sp. P1., ed. 4, Vol. 1(1): 113 (1797). Tropical Africa and Asia, widespread. Synonym: U. scandens Benj.

Taylor was not able to assign with certainty the fragmented herbarium specimen on which Willdenow based his description of $U$. capillacea to any of the known species of section Oligocista. However it was recently identified to be conspecific with Benjamin's $U$. scandens, species number 109 of Taylor's treatment (Bhattacharyya 2003). Although that latter name is well-established and widely used in flora treatments, Willdenow's name is older and thus has to be considered priority.

Acknowledgements: I want to thank Jan Schlauer for his helpful input and for numerous fruitful discussions about Lentibulariaceae taxonomy, and Ricardo de Santiago, Sergio Zamudio, and Steve Fretwell for contributing photographs to this article.

\section{References}

Bhattacharyya, P.K. 2003. The nomenclatural type of Utricularia capillacea Willd. (Lentibulariaceae). Bulletin of the Botanical Survey of India 45: 195-200.

Fleischmann, A., and Rivadavia, F. 2009. Utricularia rostrata (Lentibulariaceae), a new species from the Chapada Diamantina, Brazil. Kew Bulletin 64: 155-159.

Gassin, R. 1993. Utricularia beaugleholei (Lentibulariaceae: subgenus Utricularia: section Pleiochasia), a new species from south-eastern Australia. Muelleria 8: 37-42.

Hu, G.W., Long, C.L., and Liu, K.M. 2007. Utricularia mangshanensis (Lentibulariaceae), a new species from Hunan, China. Annales Botanici Fennici 44: 389-392.

Janarthanam, M.K., and Henry, A.N. 1990. A new Utricularia L. (Lentibulariaceae) from Peninsular India. Journal of the Bombay Natural History Society 87: 441-442.

Janarthanam, M.K., and Henry, A.N. 1992. Bladderworts of India. Botanical Survey of India, Coimbatore. Kameyama, Y., Toyama, M., and Ohara, M. 2005. Hybrid origin and F1 dominance in the free-floating, sterile bladderwort, Utricularia australis f. australis (Lentibulariaceae). American Journal of Botany 92: 469-476.

Kameyama, Y., and Ohara, M. 2006. Predominance of clonal reproduction, but recombinat origins of new genotypes in the free-floating aquatic bladderwort Utricularia australis f. tenuicaulis (Lentibulariaceae). Journal of Plant Research 119: 357-362.

Lowrie, A. 1998. A new species of Utricularia (Lentibulariaceae) from the south-west of Western Australia. Nuytsia 12: 37-41.

Lowrie, A. 2002. Utricularia petertaylorii (Lentibulariaceae), a new species from the south-west of Western Australia. Nuytsia 14: 405-410. 
Lowrie, A., Cowie, I.D., and Conran, J.G. 2008. A new species and section of Utricularia (Lentibulariaceae) from northern Australia. Telopea 12: 31-46.

Müller, K., and Borsch, T. 2005. Phylogenetics of Utricularia (Lentibulariaceae) and molecular evolution of the trnK intron in a lineage with high substitutional rates. Plant Systematics and Evolution 250: 39-67.

Parnell, J.A.N. 2005. An account of the Lentibulariaceae of Thailand. Thai Forest Bulletin (Botany) 33: 101-144.

Reut, M.S., and Jobson, R.W. 2010. A phylogenetic study of subgenus Polypompholyx: a parallel radiation of Utricularia (Lentibulariaceae) throughout Australasia. Australian Systematic Botany 23: 152-161.

Sardesai, M.M., and Yadav, S.R. 2008. Floral dimorphism in Utricularia janarthanamii. Carnivorous Plant Newsletter 37: 12-14.

Schlosser, E. 2003. Utricularia stygia in California, USA, and U. ochroleuca at its southern range. Carnivorous Plant Newsletter 32: 113-121.

Souza, P.C.B., and Bove, C.P. 2011. A new species of Utricularia (Lentibulariaceae) from Chapada dos Veadeiros (Central Brazil). Systematic Botany 36(2): 465-469.

Suksathan, P., and Parnell, J.A.N. 2010. Three new species and two new records of Utricularia L. (Lentibulariaceae) from Northern Thailand. Thai Forrest Bulletin (Botany) 38: 23-32.

Taylor, P. 1989. The genus Utricularia: a taxonomic monograph, London.

Thor, G. 1988. The genus Utricularia in the Nordic countries with special emphasis on $U$. stygia and $U$. ochroleuca. Nordic Journal of Botany 8: 219-225.

Yadav, S.R., Sardesai, M.M., and Gaikwad, S.P. 2000. Two new species of Utricularia L. (Lentibulariaceae) from Peninsular India. Rheedea 10: 107-112.

Yadav, S.R., Sardesai, M.M., and Gaikwad, S.P. 2005. A New Species of Utricularia L. (Lentibulariaceae) from the Western Ghats, India. Rheedea 15: 71-73.

Zamudio, S., and Olvera, M. 2009. A new species of Utricularia (Lentibulariaceae) from Guerrero, Mexico. Brittonia 61: 119-125.

\title{
THE ICPS SEED BANK an exclusive member benefit
}

The International Carnivorous Plant Society offers its members exclusive access to a variety of carnivorous plant seeds. Seeds are ordered online at the ICPS Store:

\section{http://icps.clubexpress.com/}

The Seed Bank cannot exist without seed donations. Information about growing carnivorous plants from seed and donating seeds to the Seed Bank are at the ICPS public web site:

\section{http://www.carnivorousplants.org/seedbank}

If you do not have access to the Internet, please send seed order form requests to:

\author{
International Carnivorous Plant Society \\ 1564-A Fitzgerald Drive, PMB 322 \\ Pinole, CA 94564-2229
}

JOHN BRITTNACHER, Seed Bank Manager, john@carnivorousplants.org 